UDC 911.52

\title{
LANDSCAPE DYNAMICS SPECIFIC FEATURES OF THE RIVER VOLGA ESTUARINE NATURAL SYSTEMS PARTICULAR LONG INUNDABLE TERRITORIES
}

\author{
Valov M.V., Barmin A.N., Probst E.N., Eroshkina O.S., Larin A.V. \\ Astrakhan State University, Astrakhan, Russian Federation, \\ e-mail:m.v.valov@mail.ru
}

Multi-method landscape-ecological researches results on stationary parts in the river Volga delta, transformed to rank of natural sanctuary in the period of 1978-2016 are presented in this work. The main landscape dynamics tendencies are discovered, natural and anthropogenous factors of soil and vegetation cover are estimated for peculiar long inundable territories: water-soluble salts cationicanionic analysis and their migration specific features and accumulation in dependence of the limited natural and anthropogenous factors changes for long inundable soil cover for forty years period; integrated effect of meteorological, hydrological, adaphic and anthropogenous factors cumulative changes on different years fluctuations and seral vegetational change for vegetation was revealed. Multi-year researches results show that the main factors, defining content and highly soluble salts radial migration in soils, also vegetation productivity and its species composition are hydrological regime (most of all - spring-summer floodings character) and territory climatic specific features. However, it is necessary to take into account local secondary effects influence, which can have an effective refracted impact on ambient background signals besides the main primary factors effect.

Keywords: the river Volga delta; landscape structure; inundation; soil geochemistry; vegetation dynamics; deltoid ecosystems.

\section{Introduction}

Deltoid plains landscapes are natural dynamic structure and create complicated structure of deltas unique ecological system. The landscape functioning process understanding of this type can be achieved only on the basis of geosystem approach, providing scientific mission solution of the deltoid system structural-dynamic analysis (Zaletaev et al., 2000).

Important landscape component and variation indicator in its structure and functioning is soil and vegetation cover. It is necessary to reveal environment factors, defining landscape links cause-effect specific features to reveal and analyze this component functioning regularities. Some factors can be distinguished such as annual volume runoff and springsummer floodings volume, spot height at the river normal water level, cattle grazing and mowing, latitudinal position for most estuarine natural systems of subarids and arids territories. These factors according to their influence typically integrated, effecting simultaneously on the soil humidity, its air capacity, temperature and other ecotope properties (Golub and Barmin, 1994; Golub and Barmin, 1995; Valov et al., 2015).

The main factor effecting soil and vegetation cover dynamics of the river Volga estuarine natural system is spring-summer floodings, under which aqueous run-off for the second quarter after coordinated hydroelectrical systems building and hydrological regime control is understood (Mikhailov et al., 2000; Barmin and Valov, 2015). The water factor importance in river landscape functioning due to the fact that river runoff anthropogenous changes, hydrographic environment redevelopment, sea level fluctuations stimulate hydrodynamic process complex development and transformation centers impact of biogeocenotic cover through the sequence ecological lines rows (Salnikov, 2011; Barmin et al., 2016).

Moreover, landscape dynamic specific features in the river Volga delta are defined by the vegetation features, its high transpiration possibilities, small quantity of precipitations, high level of evaporating capacity, small air humidity in summer months, relief pattern, soils texture and their filterability, ancient Caspian deposits salt content etc. (Valov et al., 2017). 
Natural processes interference and tendencies on the anthropogenically conditioned changes can either intensify or weaken actions of the latest, therefore dynamics particularities of the river Volga delta soil and vegetation cover research obtain specific significance, as it lets to reveal environment transformation mechanisms, estimate importance and direction of arising changes and presuppose their further development ways.

\section{Investigation materials and methods}

Laboratory scientists of grassland ecology which worked in Astrakhan state teachers university (now Astrakhan state university) were placed 9 stationary areas with the purpose of soil and vegetation cover monitoring in 1978. All investigation stationary areas are located in the eastern part of the Volga delta, where anthropogenous changes of hydrological regime and vegetation cover represented in a less degree, than in its western part. Investigation stationary areas are transformed to the rank of natural monument according to the decision of Astrakhan regional council members executive committee № 616 from 04.10.1985 (Golub et al., 2011).

The areas characterize different herb phytocenosis according to the ecology, influenced by artificially regulated spring-summer floodings. They are located in central part of the islands and each of them covers relatively homogeneous floristic composition area no less 300-400 square meters.

The areas topographic elevations were fixed with the help of gradienter to the rods of the nearest water level gauge, that allowed to judge about the flooding schedule each of them. The level in them was accepted for low water stage in stream flows under steady water expenditure in the section line of the Volgogradskaya hydropower station $4000 \mathrm{~m}^{3}$ per second.

Quantity definition and composition of the grass stand top on the stationary areas began with grass cut on small areas on the soil level. Size and number of areas selected experimentally, so that mistake of defining the total grass mass doesn't exceed $15 \%$. It was impossible to achieve the smallest mistake due to the replicate corrections number increase and areas sizes under available funds. The replicate corrections number were varied from 6 till 10 , and areas size from $0,5 \times 0,5 \mathrm{~m}$ till 1,0x1,0 $\mathrm{m}$. The stronger was shown horizontal grass stand inhomogeneity the more requires replicate corrections numbers and the larger area size was necessary to provide required accuracy.

Grass stand freshly cut samples were sorted out in cameral conditions according to the types and fractures: live plants, dead grass, ground litter. Herbs, dead this year were referred to the dead grass, and to the ground litter - last year. All these fractures were dried out in the air (14-15\% humidity) and they were weighed.

Herbs classification was carried out in accordance with guidance principal of J. Brown-Blanke (Golub and Losev, 1991).

Plant abundance in the field was defined in the foliage cover percent with the following conversion in points: $+<1 \% ; 1-1-5 \% ; 2-6-15 \% ; 3-16-25 \% ; 4-26-50 \% ; 5>50 \%$.

Soil profile cut investigation with detailed description and soil samples laboratory physico-chemical analysis was carried out for stationary areas soils characterization. Humusness, extractable phosphorus and potassium, nitrogen according to the Kornfeld, water soluble salts ions were defined in the samples per absolutely arid soil. Exchange capacity of different soil horizons and exchangeable sodium content was also defined.

Ion composition definition of the aqueous extract was carried out by the testing center federal establishment state center of agrochemical service "Astrakhansky». Analyses were carried out in accordance with the effective standards: $\mathrm{Cl}^{-}$defined in the standard GOST 26425-85; $\mathrm{SO}_{4}{ }^{2-}$ - defined in the standard GOST 26426-85; $\mathrm{Ca}^{2+}$ and $\mathrm{Mg}^{2+}-$ defined in the standard GOST 26428-85; $\mathrm{Ka}^{+}$and $\mathrm{Na}^{+}-$defined in the standard GOST 26427-85; dissolved solids- defined in the standard GOST26423-85. Analyses interpretation results are carried out in accordance with the «Classification and soil diagnostic of USSR» (Egorov et al., 1977). 
Soil salinization characteristic, accept records of water extract composition, we supply with calculation of «toxic ions integrated effect», in chlorine equivalent $(\mathrm{T})$, calculated from N.I. Bazilevich and E.I. Pankovoi algorithm, which for short we call «soil solution toxicity equivalent» (Bazilevich and Pankova, 1968). The use of this equivalent in some degree observe artefacts, arising due to resolving gypsum and calcium hydrocarbonate in soil samples in laboratory conditions. Nevertheless, this indicator takes into account nonuniform different ion toxicity for vegetation (Barmin et al., 2016 b).

Calculation algorithm of soil solution toxicity equivalent is the following:

a) if $\mathrm{HCO}_{3} \geq \mathrm{Ca}$, then

$\mathrm{T}=\mathrm{Cl}+\mathrm{SO}_{4} / 5+\mathrm{HCO}_{3}-\mathrm{Ca} / 3$,

b) if $\mathrm{HCO}_{3} \leq \mathrm{Ca} \leq \mathrm{HCO}_{3}+\mathrm{SO}_{4}$, then

$\mathrm{T}=\mathrm{Cl}+\mathrm{SO}_{4}-\left(\mathrm{Ca}-\mathrm{HCO}_{3}\right) / 5$

c) if $\mathrm{HCO}_{3}+\mathrm{SO}_{4} \leq \mathrm{Ca}$, then

$\mathrm{T}=\mathrm{Cl}$

The water-soluble ions content in soil water extract was defined in quadruple replication upon layers: $0-25 \mathrm{~cm}, 25-50 \mathrm{~cm}, 50-75 \mathrm{~cm}, 75-100 \mathrm{~cm}$.

Records on the areas were carried out several times during growing season in the first years of investigation. Then, when seasonal dynamics regularities of salt content in soil were fixed, records were carried out on single basis: in the period, when grass stand top was maximum (August).

Investigations were not conducted on areas due to financial and organizational difficulties in certain years.

\section{Results and their discussion}

The areas №№ 1, 2 and 3 located within the new Caspian deltoid lowland, the areas №№ 5 and 6 are within the recent alluvial land, №№ 7, 9, 10, 13 and 14 are within new Caspian sea lowland within baer knolls extension.

Stationary area № 3 («Trostnikovy lug («Voskhod»)» phytologic natural monument), on the example of which the river Volga delta territory special long inundable territories functioning and dynamics, located in $4 \mathrm{~km}$ to the east of Astrakhan region Privolzhsky district Yablonka village (fig. 1) is situated in plain shallow degradation (height above low water level is 1,2 $\mathrm{m}$ ) and is more longtime inundable (Valov et al, 2017).

Surface area duration of stay under water on average on one month exceeds the time of this high level territory overflowing according to the depth water stage gauge as investigations show. This was taken into account while calculation the time of the area overflowing. The area is inundated annually for a period of 64 till 120 days on average for the review period of spring-summer floodings (Golub et al., 2011).

The area vegetation cover belong to the aggregation Sparganio erecti-Typhetum angustifoliae Golub et al. 1991. The main part of the grass stand top grows in the flooding period, when the soil covers with water, the great part of it is Typha angustifolia and Phragmites australis types (Golub and Losev, 1991).

The soil in the area is alluvial meadow boggy (soil cut description is set out in the table 1), medium saline, differs with very high content of nitrogen and phosphorus active forms, potassium high content (table 2) in A horizon. Salinitity quality is chloride-sulphate (Golub et al., 2011; Valov et al., 2017).

Salts amount and composition containing in soils influence significantly on vegetation growth and development. Toxic effect of these salts reveals in soil moisture osmolality increase, its availability for vegetation, mineral nutrition elements normal ration distortion, adverse impact on fertile soils characteristics (Barmin et al., 2015). 


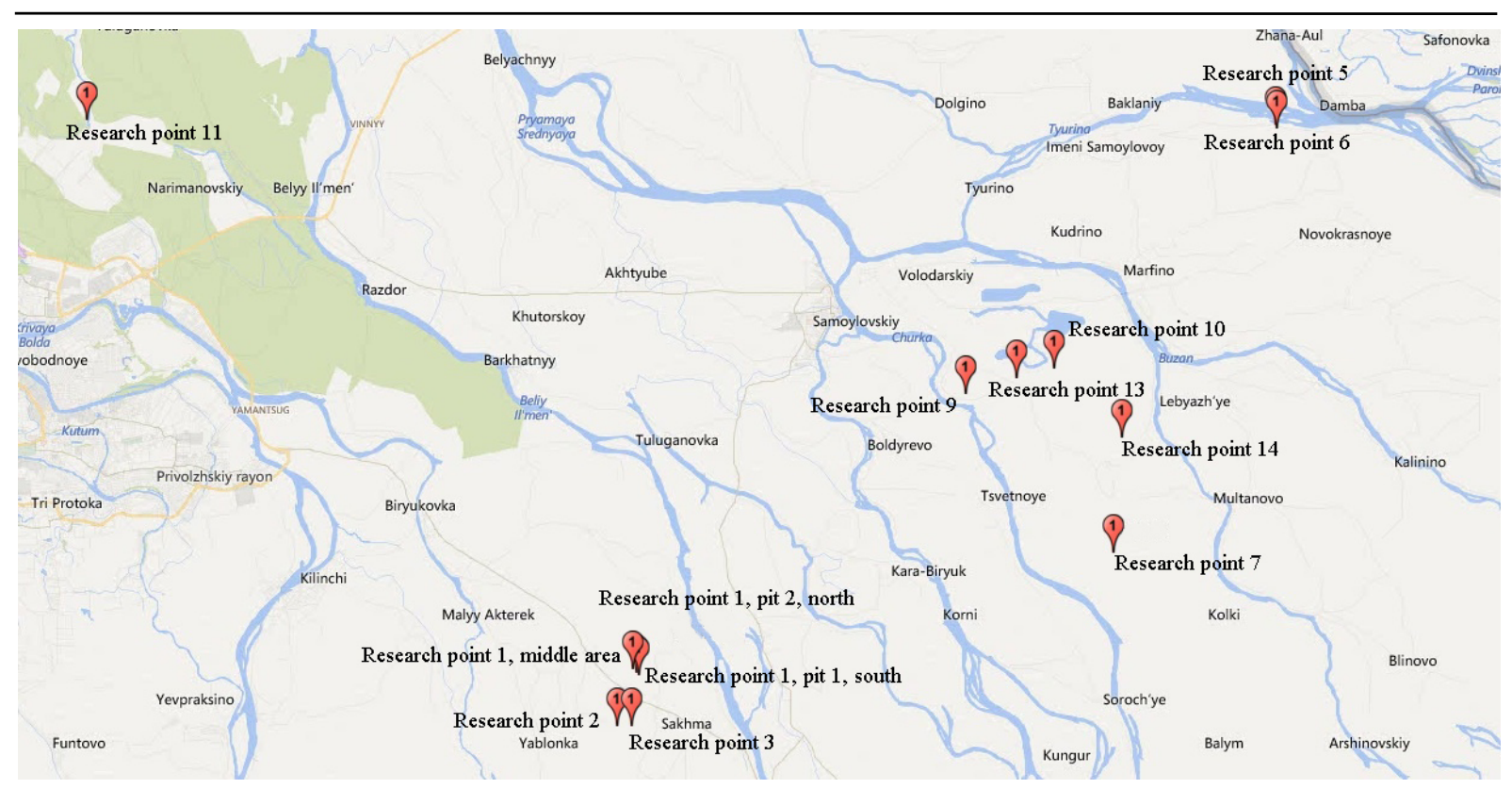

Fig. 1. Schematic diagram of stationary areas in the river Volga delta

Stationary area soil cut characteristic № 3

\begin{tabular}{|c|c|c|l|}
\hline $\begin{array}{c}\text { №, } \\
\text { Sr./No. }\end{array}$ & $\begin{array}{c}\text { Soil } \\
\text { horizon }\end{array}$ & $\begin{array}{c}\text { Cover } \\
\text { depth, } \mathrm{cm}\end{array}$ & \multicolumn{1}{|c|}{ Soil cut description } \\
\hline 1 & $A d$ & $0-10$ & $\begin{array}{l}\text { Moderate grass covered, heavy argillaceous, dark-grey, solid, wet, } \\
\text { powdered-lumpen, gleic, many roots, sharp transition }\end{array}$ \\
\hline 2 & $B$ & $10-30$ & $\begin{array}{l}\text { Light argillaceous, light-grey, porous, wet, with non pronounced structure, } \\
\text { many roots, gleic with great number of iron ochrerous patches }\end{array}$ \\
\hline 3 & A buried & $30-48$ & $\begin{array}{l}\text { Heavy argillaceous, dark-grey, solid, wet, lumpen-grain rich-nuciform, } \\
\text { gleic, with iron oxide ochrerous patches, few roots, gentle transition }\end{array}$ \\
\hline 4 & $B_{1} C$ & $48-130$ & $\begin{array}{l}\text { Agrillaceous, greyish-light-brown, very wet, solid, gleic, rare reduced iron } \\
\text { ochrerous patches }\end{array}$ \\
\hline
\end{tabular}

Some soil chemical indicators on the stationary area №3

\begin{tabular}{|c|c|c|c|c|c|c|}
\hline \multirow[t]{2}{*}{ Horizon } & \multirow{2}{*}{$\begin{array}{l}\text { Humus } \\
\text { content }\end{array}$} & \multicolumn{3}{|c|}{$\begin{array}{l}\text { Active form content, mg-eq of } \\
\text { soils }\end{array}$} & \multirow{2}{*}{$\begin{array}{l}\text { Exchange capacity } \\
\text { mg-eq on } 100 \mathrm{~g} \text { of } \\
\text { soils }\end{array}$} & \multirow{2}{*}{$\begin{array}{l}\text { Exchangeable } \mathrm{Na} \\
\text { mg-eq on } 100 \mathrm{~g} \text { of } \\
\text { soils }\end{array}$} \\
\hline & & $\mathrm{Na}$ & $\mathrm{P}_{2} \mathrm{O}_{5}$ & $\mathrm{~K}_{2} \mathrm{O}$ & & \\
\hline $0-10$ & 8,42 & 331,5 & 77,5 & 450,0 & 50 & 0,29 \\
\hline $10-30$ & 0,78 & 87,5 & 42,0 & 60,0 & 17 & 0,11 \\
\hline $30-48$ & 3,75 & 112,0 & 28,5 & 124,3 & 45 & 0,35 \\
\hline $48-130$ & Not defined & 56,0 & 31,5 & 191,0 & 41 & 0,56 \\
\hline
\end{tabular}

Highly-soluble salt amount reduction on the stationary area from 1978 to 1983 (fig. 2) (on 72\%) connected with great spring-summer floodings volume, especially in 1979 (146 cubic $\mathrm{m}$ at the rate of $110 \mathrm{~km}^{3}$ ) (fig. 3) and their duration, nevertheless, the great amount of precipitation fell for the foliated season (Valov et al., 2015).

Some highly-soluble salt content increase and soil solution growth in 1984 is explained by aqueous run-off decrease for the second quarter this year (in comparison with preceding period), little amount of precipitations at the current high evaporating capacity level (Sazhin et al., 2003; Barmin et al., 2015).

Following water-soluble salts ion content decrease in the area soil profile in 1987, connected with increased flooding volume, precipitation amount corresponded to the normal annual indicators, however mean air temperature and correspondingly, evaporating capacity 
degree, but in 1990 was very high run-off volume for the second quarter $\left(152 \mathrm{~km}^{3}\right)$ and area overflowing duration (120 days is a maximum rate for the all investigation years).

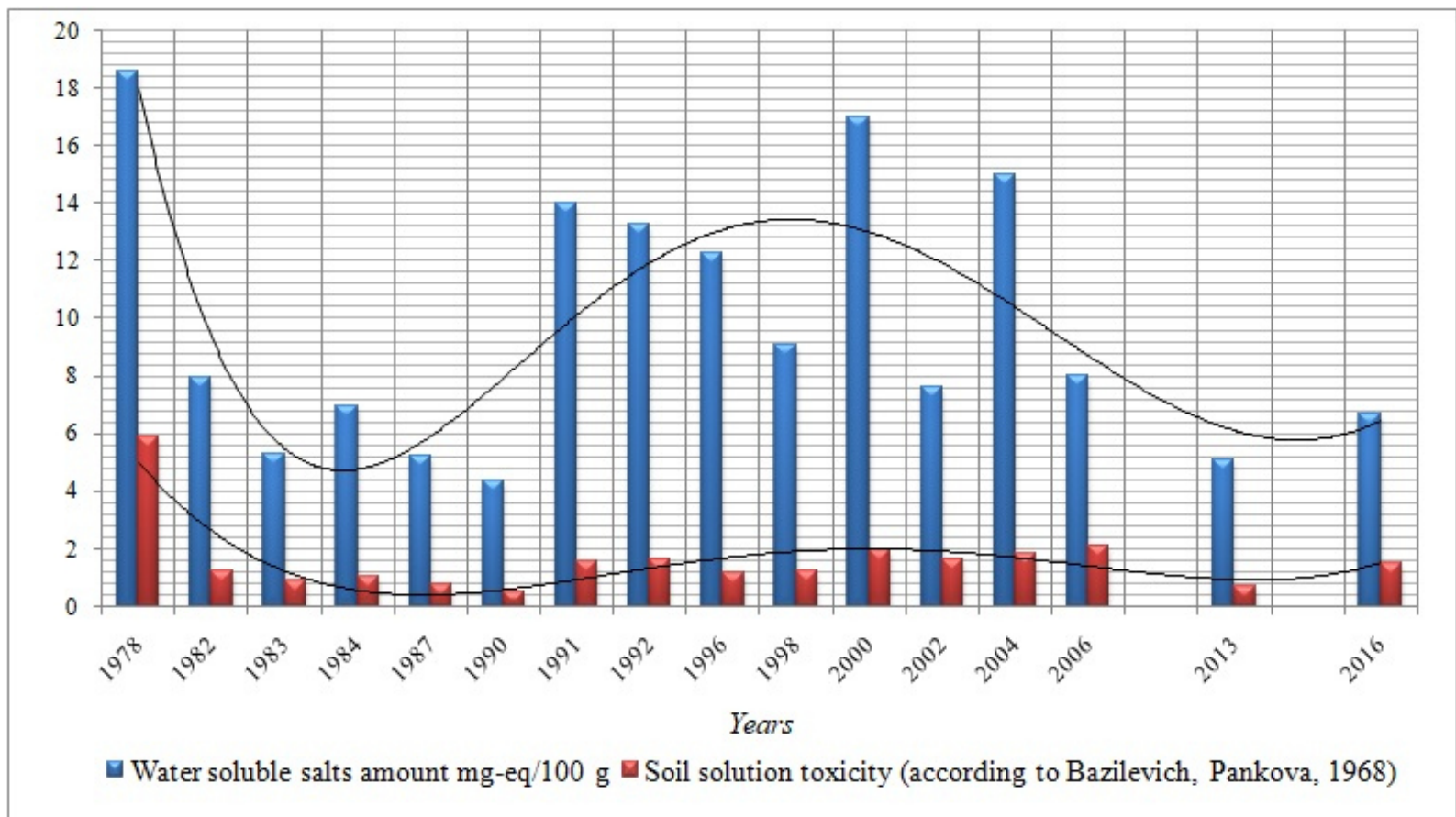

Fig. 2. Highly soluble salts amount dynamics and soil solution toxicity on the stationary area №3

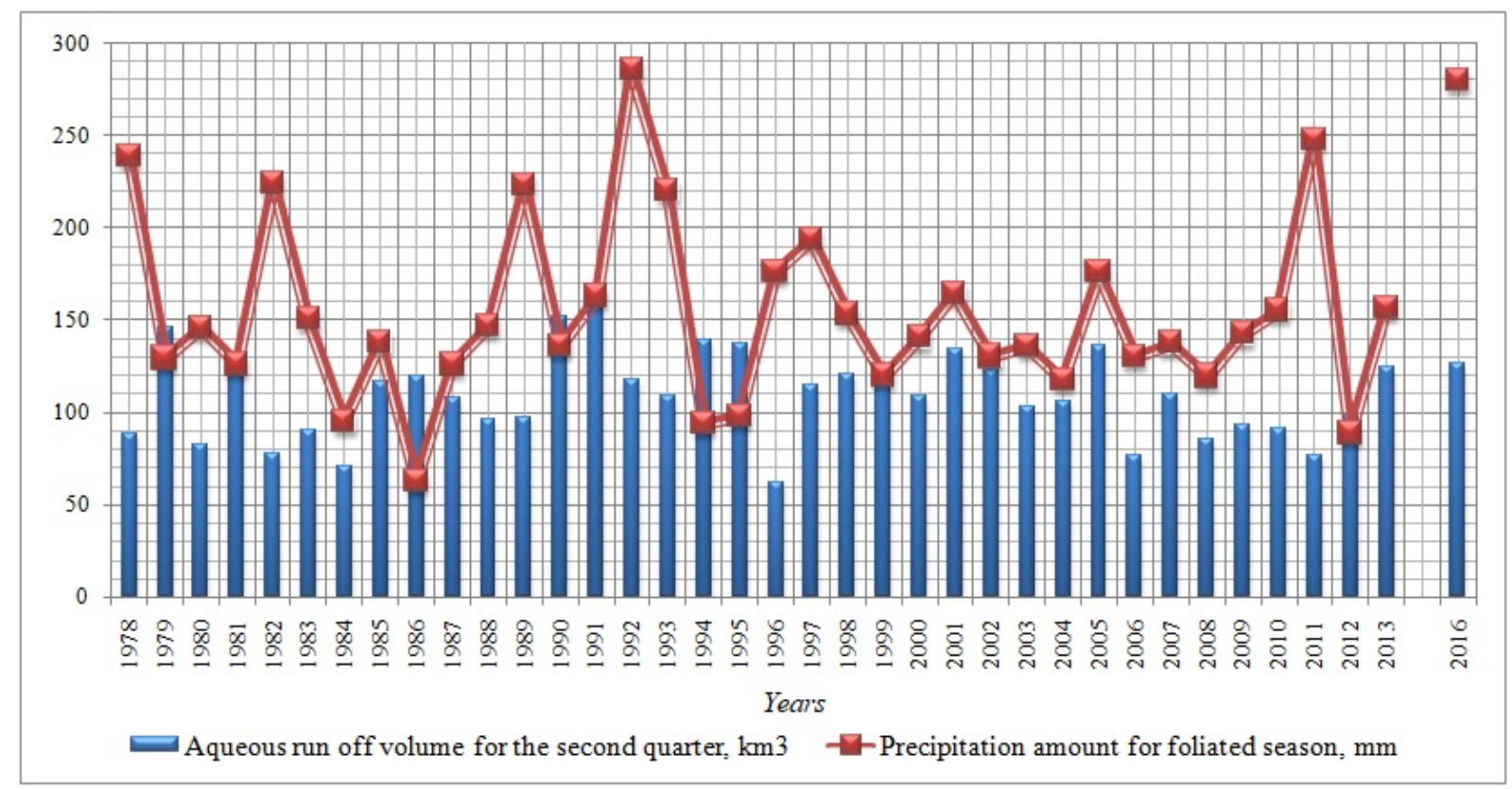

Fig. 3. Meteo-hydrologic indicators dynamic according to Astrakhan hydrometeorological centre

Highly-soluble salt sharp increase in 1991 set wondering. Flooding volume was maximum this year for the monitoring period, it was $159 \mathrm{~km}^{3}$, precipitation amount was 150 $\mathrm{mm}$ and it was believed further stationary area soil cover desalinization according to the climatic and hydrologic indices, however salt content was increased more than in 3 times in comparison with indicators in 1990 (fig. 4, fig. 5). Most probably that watersoluble content increase connected with irrigated ploughed field creation in $300 \mathrm{~m}$ from the area. 
Precipitation increase for the foliated season in 1992 (280 $\mathrm{mm}$ is a maximum value for all investigation years) and average air temperature decrease effected on watersoluble salts amount decrease in soil profile.

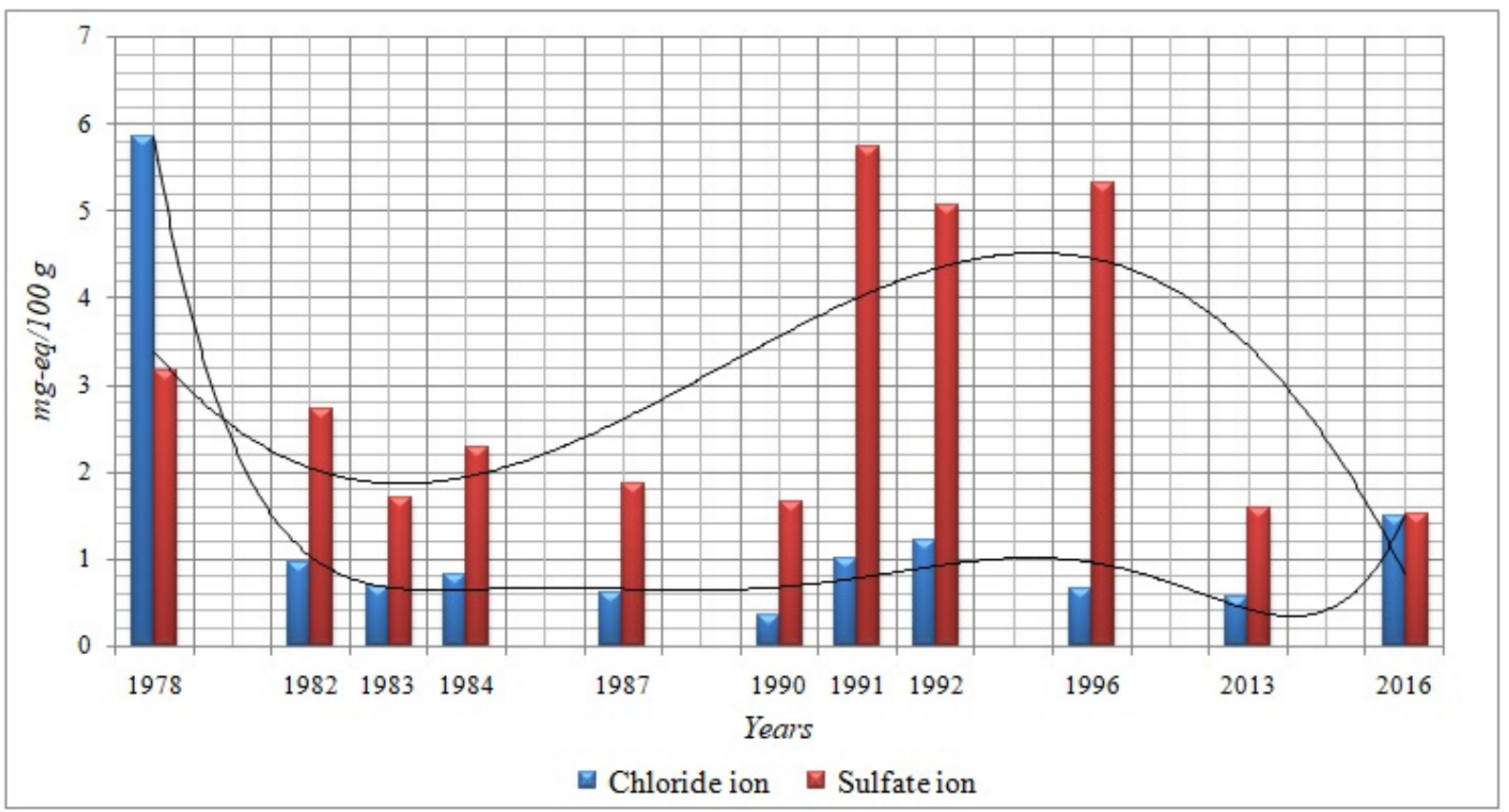

Fig. 4. Some anions content dynamics in the area soil cover

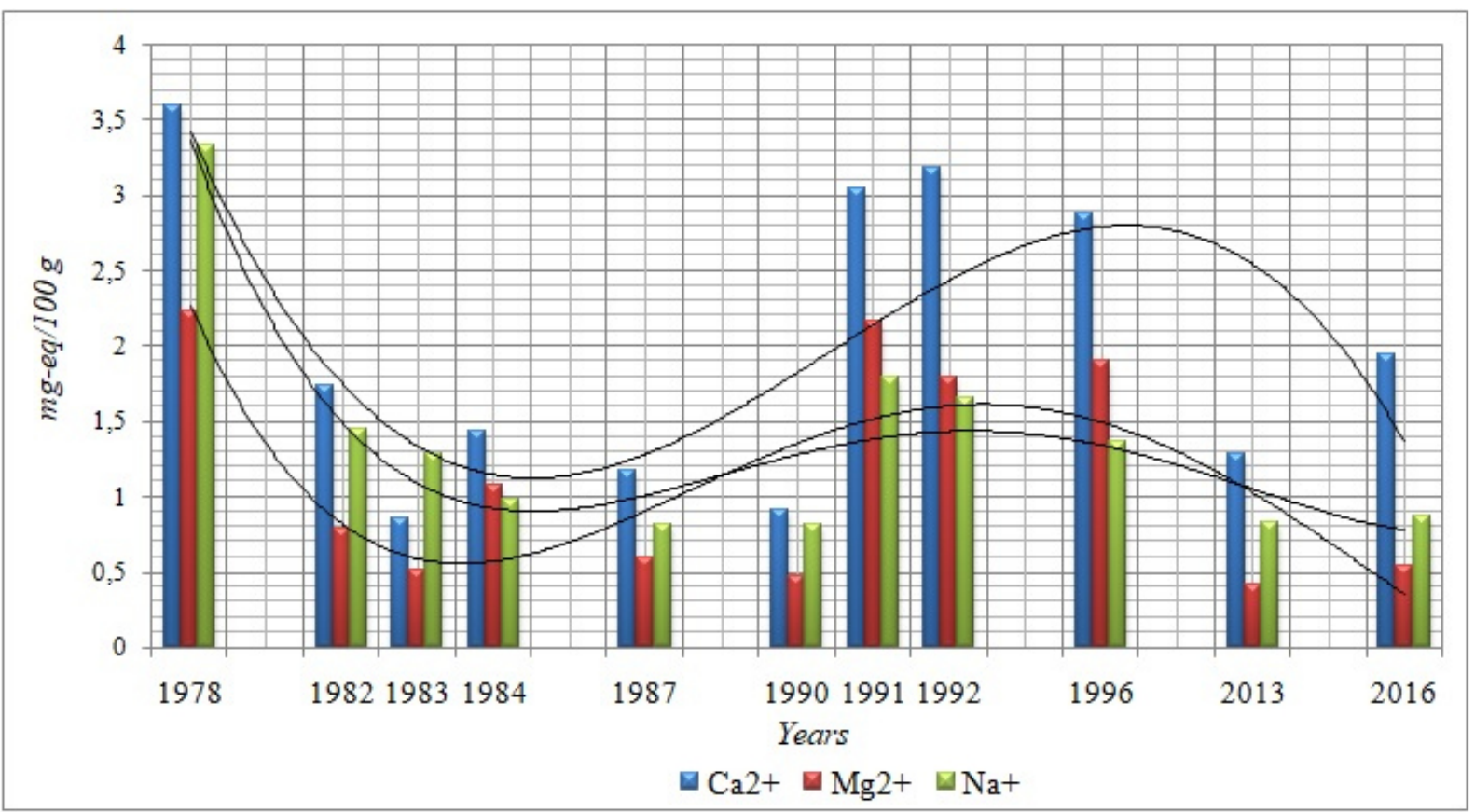

Fig. 5. Some cations content dynamics in the area soil cover

1996 was characterized by devastatingly small flooding volume $\left(62 \mathrm{~km}^{3}\right)$ and the highest average air temperature for foliated season $\left(20,3^{\circ} \mathrm{C}\right)$, but watersoluble salts content wasn't increased, but instead of it decreased in comparison with previous values 1991 and 1992. This phenomenon can be connected with several reasons. Floodings were high and in 1994 and 1995 and significant highly-soluble salts amount in this period was washed out from soil profile. Duration and maximum level of water hoisting in the flooding period were very little in 1996 and high-mineralized underwaters level were decreased in comparison with 
previous investigation years, that plays an important role in conditions of exudative regime. Besides, August and September (samples collection time) were characterized by high precipitation amount, that was conductive to high-soluble salts removal down to the soil profile.

Watersoluble salts amount decrease in 1998 was explained by the aqueous run-off volume increase for the second quarter (also previous year 1997 was water-abundant) (Barmin et al., 2015 a).

The irrigated tilled area use in 2000 and 2004 is linked with the natural causes (some flooding decrease, small precipitation amount and high air temperatures for foliated season) led to the abrupt salinity degree increase and soil solution toxicity.

Soil profile desalinization and soil solution toxicity in 2002 and 2013 connected with the high volumes and long-term period of spring-summer floods, besides tilled areas were not used (Valov et al., 2017).

Considered changes of hydrometeorological, anthropogenous and edaphic conditions on stationary areas affected on its plant cover dynamics.

In virtue of historically developed autoregulation adaptive mechanisms monocyclic climatic anomalies, even scorching, usually are incompetent to cause phytocoenosis destruction (Kurkin, 1994), that is why yielding capacity on the area decrease wasn't noticed in spite of the anomalistic little flooding in 1996.

The aqueous run-off volume increase, flood duration and maximum water hoisting level led to the watersoluble salts content decrease in soils of considering area, soil profile toxicity decrease, change of more chloride-sulphate salinization toxicity on sulphate-chloride and sulphate (Golub et al., 2017) for the second period from the beginning of investigations till the beginning of 2000 years, that was conducive to the constant vegetation productivity increase.

The main stationary area biomass percent is herbs (fig. 6), productivity of which is growing due to the Typha angustifolia species.

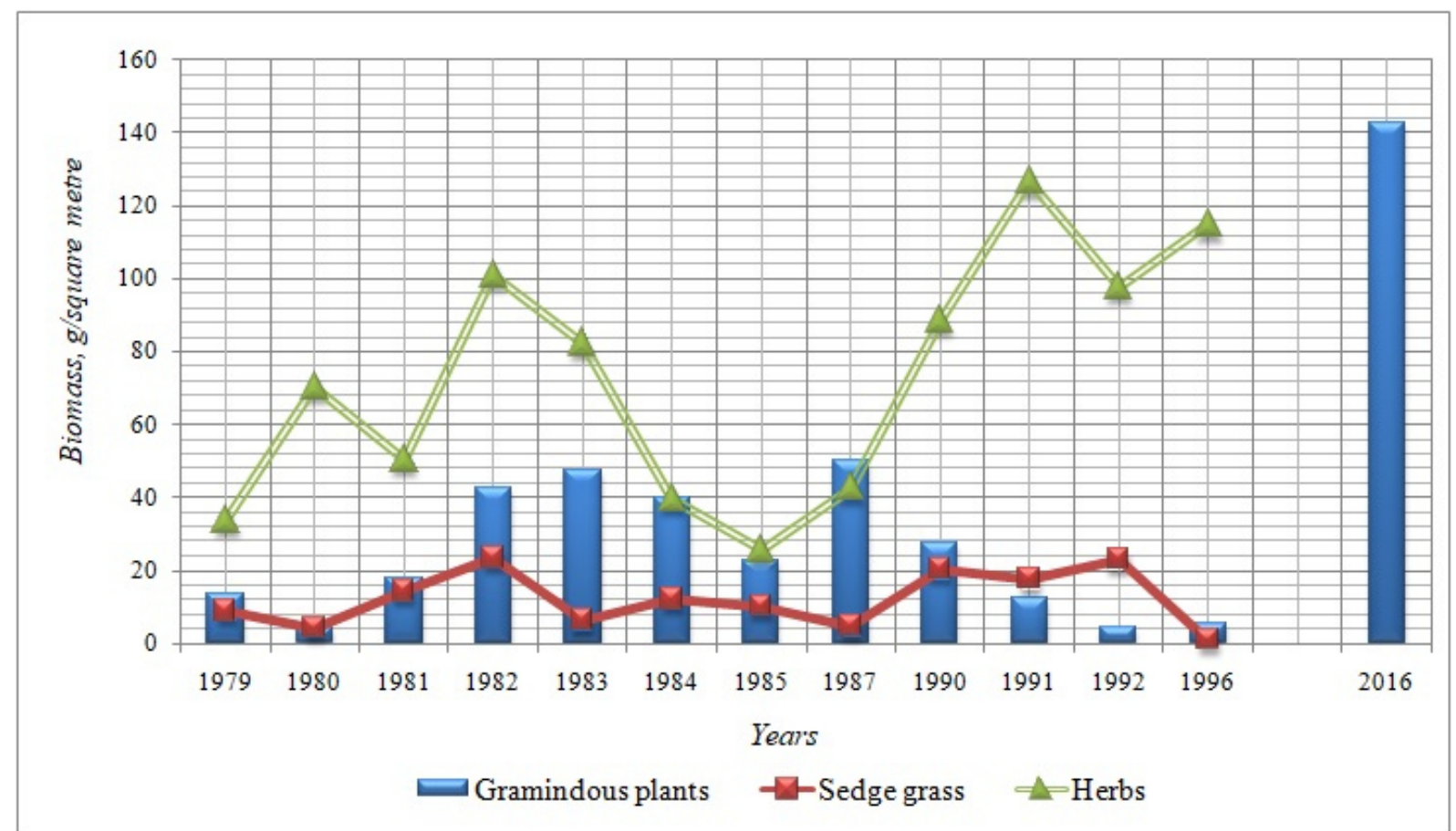

Fig. 6. Grass stand top dynamics productivity of the vegetation groups on the stationary area №3.Gramineous plants productivity (Phragmites australis, Phalaroides arundinacea, Agrostis stolonifera, Hierochloe repens) was increased till 1983, after that intended decrease of their representation was noticed up to 1996 
Vegetation biomass, belong to the sedge grasses group (Eleocharis palustris, Carex vesicaria, Scirpus lacustris, Bolboschoenus maritimus) fluctuated, productivity maxima were noticed in 1982, 1990, and 1992, after that biomass amount of this vegetation group decreased abruptly.

We see the reason of the productivity growth on the area 33 in greater ecotope moisture content. This confirm either hygrophyte productivity increase Eleocharis palustris, Scirpus lacustris, Typha angustifolia or mesohygrophyte representation decrease Phalaroides arundinacea. Phragmites australis representation was decreased in last years.

The process of meadow type composition depauperization and monodominant community with Typha angustifolia formation was noticed on the area from 1996 till 2002, later in 2013, probably, due to the moisture content decrease of this territory, besides Typha angustifolia, gramineous plants (Phragmites australis) and sedge grasses (Scirpus lacustris, Carex visicaria) were included in dominants. Abnormal low flooding levels 2014 and 2015 led to the dieaway of the Typha angustifolia top, Phragmites australis were absolute dominants on the area, productivity of which increased abruptly till $138,4 \mathrm{dt} / \mathrm{ha}$ ( $66 \%$ from the total biomass) and Scirpus lacustris (productivity 67,2 dt/ha, $32 \%$ from the total biomass).

It is interesting to mark the dominant communities change on the area territory. Vegetation communities Phragmitetea group such as Calystegio-Phragmitetum, SagittarioSparganietum were prevailed everywhere on this ecotope, where Phragmites australis, Typha angustifolia were dominated (Valov et al., 2015). Ass. Sparganio erecti-Typhetum angustifoliae was dominated in 1996, monodominant communities ass. CalystegioPhragmitetum and ass.Sparganio erecti-Typhetum angustifoliae formation occurred in the period of 1996 till 2011. Representation growth of these communities, besides the Volga delta water cut increase, can be with that areas with rough, badly eaten grasses dominance (such as Typha angustifolia $u$ Phragmites australis) were not cut.

Aqueous run-off amount and duration decrease for the second quarter, observed in lower reach Volga since 2006 influenced oppressively on the listed associations, and devastatingly low flooding in 2015 led to the Typha angustifolia aerial portion dying-off (Barmin et al., 2015; Valov et al., 2015). The hygrophyte Phragmites australis is an absolutely dominant species on the area at the moment.

Generally, vegetation productivity dynamics on the stationary area belong to the group of steadily-fluctuation forms, which is characterized by abrupt biomass value fluctuation, which sometimes reflects aqueous run-off fluctuations contrastively (Kurkin, 1994; Salnikov, 2011).

\section{Coclusion}

Different types of ecological system functioning, in particular deltoid, foremost defined by cyclicity laws, the existence of not only fully reverted but partially reverted or irreversible non-cyclic processes is possible among these cycles.

Cause-consequence analysis of the river Volga delta soil-vegetation cover ecological characteristic dynamics shows that hydrological regime and climatic territory specific features are the main factors, defining the content and highly-soluble salts radial migration in soil, also vegetation productivity and its species composition (mainly spring-summer flooding character). However, it's necessary to take into account local contributory factors, besides main primary factors influence, which can have effective refracting effect on the ambient background signals.

As a result, it is necessary to conduct full ecosystem analysis, which helps to reveal not only direct landscape development background tendencies, and side effects mechanisms while investigating processes arising in natural systems of different ranks. 


\section{Reference}

1. Базилевич Н.И., Панкова Е.И. Опыт классификации почв по засолению // Почвоведение. - 1968. - № 11. - С. 3-15.

2. Бармин А.Н., Валов М.В., Иолин М.М., Шуваев Н.С. Влияние гидрометеорологических и эдафических факторов на динамику фитоценозов лугов низкого уровня дельты реки Волги // Геология, география и глобальная энергия. 2015. - № 3 (58). - C. 15-25.

3. Бармин А.Н., Валов М.В. Устьевая область реки Волги: интегральная оценка некоторых природных и антропогенных факторов, влияющих на изменение гидрологического режима // Естественные науки. - 2015. - № 2. - С. 7-15.

4. Бармин А.Н., Валов М.В., Иолин М.М., Шуваев Н.С. Природно-антропогенная трансформация растительного покрова дельтовых ландшафтов реки Волги // Географический вестник. - 2016. - № 1. - С. 78-86.

5. Бармин А.Н., Валов М.В., Шуваев Н.С. Почвенный покров дельты реки Волги: метеогидрологические изменения как факторы влияния на геохимические особенности миграции легкорастворимых солей // Научные ведомости Белгородского государственного университета. Серия Естественные науки. - 2015. - № 15 (212). - Вып. 32. - С. 145-155.

6. Валов М.В., Бармин А.Н., Бармина Е.А., Колотухин А.Ю., Куренцов И.М. Современные тенденции динамики долгопоемных фитоценозов дельтовых экосистем реки Волги // Российский журнал прикладной экологии. - 2015. - № 3. C. 3-7.

7. Валов М.В., Бармин А.Н., Колотухин А.Ю., Бармина Е.А. Влияние первичных и вторичных экологических факторов на динамику почвенно-растительного покрова долгопойменных территорий интразональных дельтовых ландшафтов реки Волги // Геология, география и глобальная энергия. - 2017. - № 2 (65). - С. 68-79.

8. Георгиади А.Г., Коронкевич Н.И., Милюкова И.П., Кашутина Е.А., Барабанова Е.А. Современные и сценарные изменения речного стока в бассейнах крупнейших рек России: Часть 2: Бассейны рек Волги и Дона. - М.: МАКС Пресс. 2014. - 216 с.

9. Голуб В.Б., Лосев Г.А. Водная и водно-болотная растительность Волго-Ахтубинской поймы и дельты р. Волги в системе классификации направления Браун - Бланке // Ботанический журнал. - 1991. - № 5. - С. 720-727.

10. Голуб В.Б., Бармин А.Н. Оценка изменений растительности средней части дельты p. Волги // Ботанический журнал. - 1994. - Т.79. - №10. - С. 84-90.

11. Голуб В.Б., Бармин А.Н. Некоторые аспекты динамики почвенно-растительного покрова дельты р. Волги // Экология. - 1995. - №2. - С. 156-159.

12. Голуб В.Б., Пилипенко В.Н., Лосев Г.А., Бармин А.Н. Характеристика абиотических факторов на территории ботанических памятников природы в низовьях Волги // Вестник Волжского университета им. В.Н. Татищева. Серия «Экология». - 2011. Выпуск 11. - С. 19-43.

13. Егоров В.В., Фридланд В.М., Иванова Е.Н., Розов Н.Н. и др. Классификация и диагностика почв СССР. - М.: Колос, 1977. - 221 с.

14. Куркин К.А. Критерии, факторы, типы и механизмы устойчивости фитоценозов // Ботанический журнал. - 1994. - № 1. - С. 3-13.

15. Михайлов B.H. Устья рек России и сопредельных стран: прошлое, настоящее и будущее. - М.: ГЕОС, 1997. - 413 с.

16. Сажин А.Н. Современные изменения климата и зональные агроэкологические проблемы (на примере Нижнего Поволжья) // Проблемы региональной экологии. 2001. - №1. - C. 14-21. 
17. Сальников А.Л. Растительный покров дельты Волги: продуктивность, динамика, кризисные процессы. - Астрахань: Астраханский государственный университет. Издательский дом «Астраханский университет», 2011. - 318 с.

18. Цаценкин И.А. Растительность и естественные кормовые ресурсы Волго Ахтубинской поймы и дельты р.Волги. - М.: Изд - во МГУ, 1962. - С. 118-192.

19. Barmin, A.N., Valov, M.V., Suvaev, N.S., Kolchin, E.A. Concerning global climate change: ninety-year trend of some climatic characteristics in the delta ecotones of the Caspian Sea region // IGCP 610 Third Plenary Conference and Field Trip «From the Caspian to Mediterranean: Environmental Change and Human Response during the Quaternary» 2230 September 2015, Astrakhan, Russia. Proceedings / Ed.: A. Gilbert, V. YancoHombach, T. Yanina. - Moscow, MSU, 2015. - pp. 26-29.

\section{СПЕЦИФИЧЕСКИЕ ОСОБЕННОСТИ ЛАНДШАФТНОЙ ДИНАМИКИ ОСОБО ДОЛГОПОЕМНЫХ ТЕРРИТОРИЙ УСТЬЕВОЙ ПРИРОДНОЙ СИСТЕМЫ Р. ВОЛГИ}

Валов М.В., Бармин А.Н., Пробст Е.Н., Ерошкина О.С., Ларин А.В. ФГБОУ ВО «Астраханский государственный университет», 2. Астрахань, Российская Федерачия e-mail:‥v.valov@mail.ru

В работе представлены результаты комплексных ландшафтно-экологических исследований на стационарных участках в дельте р. Волги, переведенных в ранг памятников природы, в период с 1978 по 2016 гг. Для особо долгопоемных территорий выявлены основные тенденции ландшафтной динамики, оценены природные и антропогенные факторы трансформации почвенно-растительного покрова: для почвенного покрова долгопоемных территорий за сорокалетний период проведен катионно-анионный анализ водорастворимых солей и особенностей их миграции и накопления в зависимости от изменений лимитирующих природных и антропогенных факторов; для растительности выявлено комплексное воздействие совокупных изменений метеорологических, гидрологических, эдафических и антропогенных факторов на разногодичные флуктуации и сукцессионные смены растительного покрова. Результаты многолетних исследований показывают, что основными факторами, определяющими содержание и радиальную миграцию легкорастворимых солей в почвах, а также продуктивность растительности и её видовой состав является гидрологический режим (прежде всего - характер весенне-летних половодий) и климатические особенности территории. Однако, помимо действия основных первичных факторов, необходимо учитывать и воздействие локальных вторичных, которые могут оказывать эффективное преломляющее воздействие на фоновые сигналы внешней среды.

Ключевые слова: дельта р. Волги, структура ландшафта, поемность, геохимия почв, динамика растительности, дельтовые экосистемы.

Поступила в редакиџюю 14.05.2019 2. 